\title{
UPAYA MENINGKATKAN KEMAMPUAN BERHITUNG MELALUI \\ PENERAPAN MODEL PEMBELAJARAN NUMBERED HEADS TOGETHER DENGAN PEMANFAATAN ALAT PERAGa SEDERHANA MATERI PEMBAGIAN SISWA KELAS II
}

\section{Sumarni ${ }^{\bowtie}$}

SDN Mlekang 3 Gajah Demak

Jawa Tengah, Indonesia

\section{Info Artikel}

Sejarah Artikel:

Diterima Juli 2016

Disetujui Oktober 2016

Dipublikasikan

Desember 2016

Keywords:

Kemampuan Berhitung, NHT, Alat Peraga

Sederhana

\begin{abstract}
The purpose of this study was to determine the effect of the application of cooperative learning model NHT (Numbered Heads Together) against numeracy class divisions II SD Negeri 3 Mlekang academic year 2014/2015. This research is a classroom action research with two cycles of stages in each cycle; preparation of action plans, giving action, observation, reflection. The subjects were all students of class II. Before learning improvement of 8 students only two students who achieve mastery learning, or 25\%, while 6 students, or $75 \%$ has not been thoroughly studied. In the first cycle of learning improvements, of 8 students there are 6 students who achieve mastery learning, or $75 \%$, whereas 2 students or $25 \%$ has not been thoroughly studied. Students' understanding of the material division two digit numbers from before repair than after the first cycle of learning improvement has increased significantly. From $25 \%$ to $75 \%$. From the results of evaluation of the individual given before using learning model NHT (Numbered Heads Together) in the form of the use of props simple, there are only 2 children of 8 students who already understand about the division number two figures, it means that only $25 \%$ of students who are capable and the rest as many as six students, or $75 \%$ of students who have not been able. After the assessment of learning media in the form of the use of simple props, interests and learning outcomes of students increased to 7 students $(87.5 \%)$. While one student (12.5\%) needs to enrichment and individual guidance, it is because the students do not attend or do not attend school during the discussion of the material supplied.
\end{abstract}

\begin{abstract}
Abstrak
Tujuan penelitian ini adalah mengetahui pengaruh penerapan model pembelajaran kooperatif tipe NHT (Numbered Heads Together) terhadap kemampuan berhitung pembagian kelas II SD Negeri Mlekang 3 Tahun ajaran 2014/2015. Penelitian ini merupakan penelitian tindakan kelas dengan dua silkus tahapan pada setiap siklusnya; penyusunan rencana kegiatan, pemberian tindakan, melakukan observasi, refleksi. Subjek penelitian adalah semua siswa kelas II. Sebelum perbaikan pembelajaran dari 8 siswa hanya 2 siswa yang mencapai ketuntasan belajar atau $25 \%$, sedangkan 6 siswa atau 75 $\%$ belum tuntas belajar. Pada perbaikan pembelajaran siklus I, dari 8 siswa terdapat 6 siswa yang mencapai ketuntasan belajar atau $75 \%$, sedangkan 2 siswa atau $25 \%$ belum tuntas belajar. Pemahaman siswa terhadap materi pembagian bilangan dua angka dari sebelum perbaikan dibanding setelah perbaikan pembelajaran siklus I mengalami peningkatan yang signifikan. Dari $25 \%$ menjadi $75 \%$. Dari hasil evaluasi individu yang diberikan sebelum menggunakan model pembelajaran tipe NHT (Numbered Heads Together) berupa pemanfaatan alat peraga sederhana, hanya ada 2 anak dari 8 siswa yang sudah mengerti tentang pembagian bilangan dua angka tersebut, itu artinya hanya $25 \%$ siswa yang mampu dan sisanya sebanyak 6 siswa atau $75 \%$ siswa yang belum mampu. Setelah melakukan kajian tentang media pembelajaran berupa pemanfaatan alat peraga sederhana tersebut, minat dan hasil belajar siswa meningkat menjadi 7 siswa $(87,5 \%)$. Sedangkan 1 siswa $(12,5 \%)$ perlu pengayaan dan bimbingan secara individu, hal ini disebabkan karena siswa tidak mengikuti pelajaran atau tidak masuk sekolah saat pembahasan materi diberikan.
\end{abstract}

(C) 2016 Universitas Muria Kudus

Alamat korespondensi:

Program Studi Pendidikan Guru Sekolah Dasar

Fakultas Keguruan dan Ilmu Pendidikan Universitas Muria Kudus

Kampus UMK Gondangmanis, Bae Kudus Gd. L. It I PO. BOX 53

Kudus

Tlp (0291) 438229 ex.147 Fax. (0291) 437198

E-mail: sumarni61@gmail.com
p-ISSN 2087-9385

e-ISSN 2528-696X 


\section{PENDAHULUAN}

Matematika merupakan salah satu pelajaran yang wajib dipelajari oleh setiap siswa sejak duduk dibangku SD sampai SMA. Matematika dipelajari karena dianggap penting sebagai bekal hidup. Dalam hidup kita selalu dihadapkan dengan banyak perhitungan, ilmu hitung serta logika yang amat diperlukan agar kita berpikir dengan benar, karena logika adalah bagian penting dari matematika. Tidak kalah pentingnya, teknologi modern dan sains modern hanya dapat maju dengan bantuan matematika.

Salah satu karakteristik matematika adalah mempunyai obyek yang bersifat abstrak. Sifat obyek matematika yang abstrak pada umumnya membuat materi matematika sulit ditangkap dan dipahami. Mengingat bahwa obyek dalam matematika bersifat abstrak, maka diperlukan media yang tepat untuk menjembatani proses pembelajaran matematika, sehingga materi matematika mudah dipahami oleh siswa. Penggunaan media yang tepat dapat menciptakan proses pembelajaran yang lebih baik, sehingga menciptakan hasil belajar. Disamping itu di lingkungan belajar, hubungan antara siswa dan guru turut mempengaruhi keberhasilan proses pembelajaran. Betapa pentingnya kedudukan guru dalam proses pembelajaran di kelas, karena guru merupakan motor penggerak yang akan menentukan berhasil tidaknya seorang siswa.

Keberhasilan siswa dapat ditentukan dari beberapa faktor antara lain faktor internal dan eksternal. Faktor yang timbul dari dalam diri siswa, antara lain kemauan, rasa takut, tingkat intelektual dan sebagainya. Sedang faktor eksternal dapat berupa sikap guru, pendekatan pengajaran, metode, alat peraga, dan sumbersumber lain. Kesemuanya itu akan berpengaruh terhadap keberhasilan pembelajaran. Namun menurut hasil pengamatan peneliti kesalahan yang biasa dilakukan guru dalam membelajarkan matematika di tempat peneliti hingga siswa cepat menjadi bosan adalah (1) Dalam membelajarkan matematika guru hanya berpedoman pada buku pegangan. (2) Penyampaian konsep sarat dengan hafalan-hafalan. (3) Kegiatan pembelajaran masih monoton. (4) Kurang memperhatikan keterampilan prasarat.

Keterampilan prasarat memang sangat diperlukan dalam pembelajaran, hal tersebut seperti yang dikemukakan oeh Gagne (dalam Degeng:1997:4) bahwa setiap mata pelajaran mempunyai prasarat belajar (learning prerequisites). Dalam hubungannya dengan pembelajaran matematika maka keterampilan prasarat yang harus dikuasai siswa umumnya adalah hitung dasar yang meliputi: penjumlahan, pengurangan, perkalian, dan pembagian .Sebaik apapun konsep matematika yang disampaikan oleh guru pada pembelajaran matematika namun bila siswa tidak menguasai hitung dasar sebagai keterampilan prasaratnya maka hasil pembelajaran kurang memuaskan.

Berdasarkan hasil penyelenggaraan proses pembelajaran guru belum memberikan variasi model mengajarnya yaitu masih menggunakan diskusi dan tanya jawab. Model pembelajaran yang kurang bervariasi menyebabkan siswa mengalami kejenuhan yang berakibat proses pembelajaran tidak berlangsung optimal sehingga pengalaman belajar dan kemampuan berpikir kritis siswa tidak dapat terlaksana dengan baik. Sementara berpikir kritis siswa akan tumbuh dan terpelihara apabila kegiatan pembelajaran dilaksanakan secara bervariasi, salah satunya melalui variasi model pembelajaran.

Berdasarkan kondisi di atas, salah satu model pembelajaran yang dapat memfasilitasi ketercapaian proses pembelajaran adalah melalui inovasi pembelajaran kooperatif. Pembelajaran kooperatif ada beberapa tipe, antara lain tipe NHT (Numbered Heads Together) Pembelajaran kooperatif tipe NHT (Numbered Heads Together) lebih memungkinkan siswa untuk lebih aktif dan bertanggung jawab penuh untuk memahami materi pelajaran, baik secara berkelompok maupun individual. Pembelajaran tersebut akan melatih siswa untuk berpikir kritis dan meningkatkan prestasi belajar siswa. Berdasarkan karakteristik tersebut maka model kooperatif tipe NHT (Numbered Heads Together) akan sangat tepat apabila diterapkan pada materi pembelajaran pembagian.

Berdasarkan pada identifikasi dan batasan masalah, maka permasalahan yang dirumuskan dalam penelitian ini adalah: "Apakah terdapat pengaruh penerapan model pembelajaran kooperatif tipe NHT (Numbered Heads Together) terhadap kemampuan berhitung pembagian kelas II SD Negeri Mlekang 3 Tahun ajaran 2014/2015?"

\section{METODE PENELITIAN}

Penelitian ini merupakan penelitian tindakan kelas. Penelitian ini dilaksanakan pada kelas II SD Negeri Mlekang 3, Kecamatan Gajah, Kabupaten Demak, Provinsi Jawa Tengah. Penelitian ini dilaksanakan pada Semester II Tahun Pelajaran 2014/ 2015. Subjek penelitian adalah semua siswa kelas II SD Negeri Mlekang 3 Tahun Pelajaran 2014/2015.

Data yang diperoleh diambil dari hasil kegiatan yang berhubungan dengan pembelajaran matematika hitung pembagian pada siswa kelas II SD Negeri Mlekang 3. Adapun data yang 
diperoleh dalam penelitian ini adalah: (1) data angket siswa, pengamatan peneliti terhadap hasil pembelajaran matematika, (2) Dari hasil catatan perilaku siswa selama pembelajaran berlangsung, (3) dari hasil belajar siswa melalui tes yang dilakukan selama proses pembelajaran pembagian.

Prosedur pengumpulan data dilakukan berdasarkan bentuk data yang ingin diperoleh. Untuk mengetahui kemampuan menghitung pembagian dilakukan dengan tes hasil belajar dalam bentuk skor. Sedangkan data tentang sikap dan perilaku serta tanggapan siswa selama pembelajaran perkalian dilakukan melalui pengamatan pada subjek penelitian.

Data mengenai pelaksanaan pembelajaran dalam kelas diperoleh melalui catatan lapangan. Oleh karena itu peneliti mempunyai tugas rangkap yaitu sambil mengajar guru juga mengumpulkan data. Maka untuk memperoleh data yang akurat, dalam mendapatkan data guru bekerja sama dengan teman sejawat untuk melakukan pengamatan. Selanjutnya dari hasil pengamatan didiskusikan bersama. Hasil dari diskusi akan digunakan sebagai pedoman untuk menentukan refleksi dalam melakukan tindakan selanjutnya. Pemberian tindakan ini dilakukan berulang-ulang (siklus) agar dapat diambil kesimpulan yang sesuai dengan fokus penelitian.

Penelitian tindakan kelas ini dilakukan dalam dua suklus kegiatan yaitu siklus 1 dan siklus 2, masing-masing siklus terdiri atas empat tahap dan dilakuan dalan satu pertemuan. Hal ini dilakukan karena terbatasnya waktu yang tersedia. Tahapan kegiatan setiap siklus adalah: (1) menyusun rencana kegiatan,(2) melakukan tindakan, (3) melakukan observasi, dan (4) membuat analisis yang di lanjutkan dengan refleksi. Pada penelitian ini yang melaksanakan kegiatan mengajar adalah peneliti, sedangkan yang bertindak sebagai observer adalah guru kelas IV dibantu oleh teman sejawat.

\section{Siklus-1}

\section{a. Penyusunan Rencana Kegiatan}

Pada tahap ini guru menysun rencana pembelajaran berdasar pokok bahasan yang akan diajarkan yaitu kemampuan berhitung pembagian melalui alat peraga, dengan urutan:

1. Menyiapkan peralatan pembelajaaran

2. Menyusun silabus.

3. Menyusun rencana pembelajaran

4. Menyusun instrumen yang terdiri atas:

a. lembar pengamatan aktivitas dan koopertif siswa.

b. Lembar pengamatan untuk guru c. Soal evaluasi

5. Menentukan jadwal tindakan kelas.

b. Pemberian Tindakan

1. Sebagai penjajagan guru memberikan pertanyan kepada siswa.tentang pembagian.

2. Guru memberikan apersepsi tentang pentingnya kemampuan menghitung pembagian.

3. Guru mengajak siswa untuk melakukan penghitungan pembagian dengan menggunakan alat peraga sederhana yaitu menggunakan lidi dan manik-manik.

4. Setelah semua soal selesai dikerjakan, Siswa dibentuk dalam kelompok. Tiap kelompok menerima lidi dan manik-manik dan ditulis pada lembar kerja untuk didelesaikan bersama.

5. Setelah kelompok terbentuk, guru memberi nomor kepala kepada setiap siswa dalam kelompok dan memberi tugas sesuai masingmasing nomor siswa.

6. Guru memandu siswa dalam berdiskusi.

7. Setelah selesai berdiskusi, siswa mempresentasikan hasil diskusi kemudian ditanggapi oleh kelompok lain.

8. Guru memberi penguatan terhadap hasil diskusi siswa.

9. Guru memberi penegasan serta pemantapan materi.

10. Guru mengulas kembali materi yang telah dibahas.

11. Guru mengadakan evaluasi

\section{c. Melakukan Observasi}

Pada saat kegiatan pembelajaran berlangsung guru kelas II sebagai observer beserta teman sejawat melakukan pengamatan dan mencatat kejadian-kejadian selama pembelajaran berlangsung. Hasil catatan observasi bermanfaat untuk pengambila keputusan dalam kegiataan selanjutnya yaitu refleksi.

\section{d. Refleksi}

Dari hasil pengamatan yang dilakukan peneliti sebagai guru, hasil pengamatan guru kelas II, dan pengamatan teman sejawat dikumpulkan dan dibahas bersama untuk mendapatkan kesamaan pandangan terhadap tindakan awal pada siklus ke-1. Hasil diskusi tersebut akan dijadikan bahan untuk menentukan langkah tindakan selanjutnya pada siklus ke-2.

\section{Siklus-2}

\section{a. Penyusunan rencana kegiatan}

Rencana kegiatan disusun berdasar hasil analisis dan reflesi selama siklus-1. Topik yang dibahas pada siklus-2 ini adalah pembagian.

\section{b. Pemberian Tindakan}


Tindakan II ini dilakukan berdasar masalah yang masih ada pada siklus-1. Tindakan lebih ditekankan pada aktifitas, kerja sama, dan kemampuan menghitung pembagian.

\section{c. Pelaksanaan Observasi}

Pada saat guru mengajar guru kelas IV bersama teman sejawat melakukan pengamatan sebagaimana yang dilakukan pada siklus-1.

\section{d. Analisis dan Refleksi}

Pada akhir tindakan II dilakukan analisis dan refleksi terhadap kegiatan yang telah dilakukan. Dan hasil dari analisis dan refleksi ini disusun kesimpulan dan saran dari seluruh kegiatan pada siklus-2.

\section{HASIL PENELITIAN DAN PEMBAHASAN}

\section{A. Deskripsi per Siklus}

\section{Siklus I}

\section{a. Perencanaan}

Peneliti dengan teman sejawat berdiskusi mendindaklanjuti dari refleksi pra siklus untuk menentukan langkah-langkah penyusunan RPP siklus I dengan mengimplikasikan pembelajaran model NHT ( Numbered Heads Together ). Langkah-langkah pembelajaran terlampir pada laporan ini. Untuk melakukan pengamatan, peneliti juga membuat lembar observasi agar teman sejawat sebagai pengamat mempunyai fokus pengamatan sehingga tidak keluar dari tujuan pembelajaran.

\section{b. Pelaksanaan}

Sesuai dengan perencanaan yang telah disusun dengan teman sejawat maka pada tanggal 21 April 2015 perbaikan pembelajaran dilaksanakan. Langkah-langkah pembelajaran terlaksana sesuai dengan rencana perbaikan pembelajaran siklus I. pada kegiatan awal guru telah mempersiapkan siswa $100 \%$ bisa mengikuti pelajaran. Selanjutnya pembelajaran berlangsung sesuai dengan kegiatan belajar mengajar yang telah direncanakan. Kegiatan pembelajaran matematika diakhiri dengan pelaksanaan tes formatif, penilaian dan analisis nilai yang hasilnya tabel 1 ..

Tabel 1. Nilai Sebelum Perbaikan

\begin{tabular}{|l|l|l|}
\hline No & Rentang Nilai & Jumlah Siswa \\
\hline 1 & $20-29$ & - \\
\hline 2 & $30-39$ & 1 \\
\hline 3 & $40-49$ & 2 \\
\hline 4 & $50-59$ & 3 \\
\hline 5 & $60-69$ & - \\
\hline 6 & $70-79$ & 2 \\
\hline 7 & $80-89$ & - \\
\hline 8 & $90-100$ & - \\
\hline Jumlah & 8 \\
\hline
\end{tabular}

Berdasarkan tabel diatas dari 8 siswa hanya 2 siswa yang tuntas ( $25 \%$ ), sedangkan 6 siswa belum tuntas belajar (75 \%). Setelah diadakan perbaikan siklus I, maka data rentang nilai formatifnya sebagai berikut :

Tabel 2. Nilai Siklus I

\begin{tabular}{|l|l|l|}
\hline No & Rentang Nilai & Jumlah Siswa \\
\hline 1 & $20-29$ & - \\
\hline 2 & $30-39$ & - \\
\hline 3 & $40-49$ & 1 \\
\hline 4 & $50-59$ & - \\
\hline 5 & $60-69$ & 1 \\
\hline 6 & $70-79$ & 2 \\
\hline 7 & $80-89$ & 3 \\
\hline 8 & $90-100$ & 1 \\
\hline Jumlah & 8 \\
\hline
\end{tabular}

Dari rentang nilai pada tabel diatas terjadi peningkatan yaitu $25 \%$ ketuntasan sebelum siklus menjadi $75 \%$ pada siklus I. Berdasarkan data-data di atas terlihat adanya peningkatan pemahaman siswa terhadap materi pecahan sebagai perbandingan pada pembelajaran Siklus I.

Peningkatan dapat diuraikan sebagai berikut:

Sebelum perbaikan pembelajaran dari 8 siswa hanya 2 siswa yang mencapai ketuntasan belajar atau $25 \%$, sedangkan 6 siswa atau $75 \%$ belum tuntas belajar. Pada perbaikan pembelajaran siklus I, dari 8 siswa terdapat 6 siswa yang mencapai ketuntasan belajar atau 75 $\%$, sedangkan 2 siswa atau $25 \%$ belum tuntas belajar. Pemahaman siswa terhadap materi Melakukan pembagian bilangan dua angka dari sebelum perbaikan dibanding setelah perbaikan pembelajaran siklus I mengalami peningkatan yang signifikan. Dari $25 \%$ menjadi $75 \%$ atau mengalami peningkatan $50 \%$.

Dari observasi teman sejawat diperoleh data sebagai berikut:

- Kerja sama dalam berdiskusi belum optimal.

- Latihan berulang-ulang (drill) perlu ditingkatkan.

c. Menentukan instrumen pengamatan

Ada dua macam instrumen pengamatan yang digunakan dalam pembelajaran siklus 1 , yaitu lembar penilaian dan lembar observasi sistematis

1. Lembar Penilaian

Lembar penilaian digunakan peneliti untuk menulis hasil nilai siswa yang diperoleh dalam kegiatan tes formatif

\section{Lembar Observasi Sistematis}

Format observasi yang digunakan teman sejawat untuk mengamati kinerja peneliti adalah lembar observasi sistematis. Dalam format observasi dicantumkan aspek-aspek yang menjadi fokus pengamatan, dimana aspek-aspek yang 
diobservasi tersebut ditetapkan berdasarkan hasil kesepakatan antara peneliti dengan teman sejawat.

\section{d. Refleksi}

Setelah proses pembelajaran siklus 1 berakhir dan data nilai tes akhir yang diperoleh siswa dianalisis, ternyata menunjukan bahwa pembelajaran siklus 1 masih gagal, oleh karena itu peneliti mencoba mengingat kembali kejadiankejadian yang muncul yang menyebabkan gagalnya pembelajaran siklus 1 . disamping itu peneliti juga merenungkan dan sekaligus menetapkan langkah-langkah perbaikan yang akan dilakukan dalam pembelajaran berikutnya.

Hasil refleksi yang dilakukan peneliti dapat diuraikan sebagai berikut:

1. Metode yang digunakan kurang bervariatif

2. Siswa tidak focus pada pembelajan, sebagian siswa ada yang bercanda dengan temantemannya.

3. Dalam berdiskusi kelompok ada siswa yang hanya mengandalkan temannya saja.

Dari hasil refleksi tersebut, muncul gagasan peneliti untuk meningkatkan pemahaman siswa terhadap mata pelajaran Matematika dengan materi membandingkan dan mengurutkan pecahan.

Gagasan-gagasan peneliti yang akan dilaksanakan pada pembelajaran siklus-2 adalah sebagai berikut :

1. Merancang kembali pembelajaran dengan menetapkan penggunaan metode yang lebih variatif, sehingga proses pembelajaran tidak berlangsung monoton dan terkesan kaku.

2. Guru memberi arahan kepada siswa agar dapat bekerjasama yang baik dalam berdiskusi.

3. Meningkatkan pemberian motivasi pada siswa dengan cara memberikan penghargaan yang dapat menimbulkan kebanyakan pada diri anak, baik secara verbal maupun non verbal.

4. Guru memberi motivasi serta kesempatan bertanya kepada siswa.

\section{Siklus II}

\section{a. Perencanaan}

Peneliti dengan teman sejawat berdiskusi mendindaklanjuti dari refleksi siklus I untuk menentukan langkah-langkah penyusunan RPP siklus II dengan kembali mengimplikasikan pembelajaran model NHT (Numberd Heads Together). Langkah-langkah pembelajaran terlampir pada laporan ini. Untuk melakukan pengamatan, peneliti juga membuat lembar observasi agar teman sejawat sebagai pengamat mempunyai fokus pengamatan sehingga tidak keluar dari tujuan pembelajaran.

\section{b. Pelaksanaan}

Sesuai dengan perencanaan yang telah disusun dengan teman sejawat maka pada tanggal 7 Mei 2015 perbaikan pembelajaran dilaksanakan. Langkah-langkah pembelajaran terlaksana sesuai dengan rencana perbaikan pembelajaran siklus I. pada kegiatan awal guru telah mempersiapkan siswa $100 \%$ bisa mengikuti pelajaran. Selanjutnya pembelajaran berlangsung sesuai dengan kegiatan belajar mengajar yang telah direncanakan. Semua berjalan cukup lancar, tanya jawab, diskusi kelompok meningkat. Kegiatan pembelajaran diakhiri dengan pelaksanaan tes formatif, penilaian dan analisis nilai yang hasilnya terdapat pada tabel 3 berikut ini.

Tabel 3. Nilai Siklus II

\begin{tabular}{|l|l|l|}
\hline No & Rentang Nilai & $\begin{array}{l}\text { Jumlah } \\
\text { Siswa }\end{array}$ \\
\hline 1 & $20-29$ & - \\
\hline 2 & $30-39$ & - \\
\hline 3 & $40-49$ & - \\
\hline 4 & $50-59$ & - \\
\hline 5 & $60-69$ & 1 \\
\hline 6 & $70-79$ & 2 \\
\hline 7 & $80-89$ & 2 \\
\hline 8 & $90-100$ & 3 \\
\hline Jumlah & 8 \\
\hline
\end{tabular}

Berdasarkan tabel atas dari 8 siswa hanya 7 siswa yang tuntas ( $87.5 \%)$, sedangkan 1 siswa belum tuntas belajar (12.5\%).

\section{c. Pengamatan}

Instrumen yang digunakan dalam pembelajaran siklus II ada dua macam yaitu ada dua macam instrument pengamatan yang digunakan dalam pembelajaran siklus 2, yaitu lembar penilaian dan lembar observasi sistematis

\section{Lembar Penilaian}

Lembar penilaian digunakan peneliti untuk menulis hasil nilai siswa yang diperoleh dalam kegiatan tes formatif

\section{Lembar Observasi Sistematis}

Format observasi yang digunakan teman sejawat untuk mengamati kinerja peneliti adalah lembar observasi sistematis. Dalam format observasi dicantumkan aspek-aspek yang menjadi fokus pengamatan, dimana aspek-aspek yang diobservasi tersebut ditetapkan berdasarkan hasil kesepakatan antara peneliti dengan teman sejawat.

\section{d. Refleksi}

Setelah proses pembelajaran siklus-2 berakhir dan nilai tes akhir dianalisis, peneliti mencoba mengingat kembali kejadian-kejadian yang muncul selama proses pembelajaran berlangsung. 
Hasil dari refleksi yang dilakukan peneliti dapat diuraikan sebagai berikut:

1. Tetap saja ada siswa yang kurang aktif dalam pembelajaran dan ada siswa yang belum bisa mencapai ketuntasan karena faktor kelemahan berfikir.

2. Siswa lebih antusias atau termotivasi di dalam mersepon materi pelajaran yang disampaikan guru. Hal ini terbukti dengan banyaknya siswa yang sudah berani mengajukan pertanyaan tentang materi yang belum dipahami.

3. Peran serta dakam diskusi sudah cukup baik, diskusi berjalan dengan lancar, dengan sistematis sesuai denagn aturan yang telah ditentukan.

Gagal dan tidaknya suatu pembelajaran diketahui dari sejauh mana kemampuan siswa menguasai materi pelajaran yang telah disampaikan guru. Oleh karena itu, setiap proses pembelajaran hendaknya diakhiri dengan penilaian akhir. Untuk mengetahui adanya kemajuan belajar yang dimiliki oleh siswa dalam proses pembelajaran perlu diadakan tes formatif. Tes ini diberikan sesudah satu kegiatan atau unit belajar deselesaikan yang bertujuan untuk mengumpulkan data atau informasi tentang kekuatan dan kelemahan siswa dalam pelajaran.

\section{Sebelum Perbaikan}

Dari hasil tes formatif sebelum perbaikan pembelajaran sampai dengan pelaksanaan perbaikan pembelajaran siklus I dan siklus II pada mata pelajaran matematika tentang pembagian bilangan dua angka semester 2 di SD Negeri Mlekang 3 tahun pelajaran 2014/2015 dengan jumlah siswa 8 anak, diperoleh data sebagai berikut:

Hasil tes formatif sebelum perbaikan dengan jumlah siswa 8 anak diperoleh nilai sebagai berikut : 30, 40, 40, 50, 50, 50, 70, 70 . Nilai rata-rata 50 dapat disajikan dalam tabel distribusi frekuensi 4. berikut ini:

Tabel 4. Nilai Tes Formatif Sebelum Perbaikan

\begin{tabular}{|l|l|}
\hline Rentang Nilai & Jumlah Siswa \\
\hline $20-29$ & - \\
\hline $30-39$ & 1 \\
\hline $40-49$ & 2 \\
\hline $50-59$ & 3 \\
\hline $60-69$ & - \\
\hline $70-79$ & 2 \\
\hline $80-89$ & - \\
\hline $90-100$ & - \\
\hline Jumlah & 8 \\
\hline
\end{tabular}

Dilihat dari data diatas, hanya 2 dari 8 siswa yang mendapat nilai 70 keatas, nilai ratarata kelas 50 (ketuntasan belajar $25 \%$ ), artinya masih ada 6 siswa yang belum mencapai ketuntasan belajar. Dengan demikian dinilai pembelajaran yang telah dilaksanakan belum berhasil, untuk itu guru harus merancang perbaikan pembelajaran siklus I untuk memperbaiki pembelajaran sebelumnya, adapun penyebab kegagalan menurut hasil diskusi dengan teman sejawat yang dilakukan setelah refleksi adalah:

a. Belum adanya interaksi yang baik antara guru dan siswa.

b. Penggunaan metode yang kurang tepat.

\section{Perbaikan Siklus I}

Pada siklus I, peneliti memperbaiki proses pembelajaran dengan menyusun RPP (Rencana Pelaksanaan Pembelajaran) siklus I, kegiatan yang dilaksanakan mulai dari kegiatan awal, kegiatan inti, dan kegiatan akhir. Pada siklus I ini, peneliti menggunakan metode yang tepat yaitu demosntrasi, metode merupakan cara pengajaran untuk mencapai tujuan pembelajaran setelah perbaikan pembelajaran siklus I, terbukti hasil yang diperoleh siswa meningkat. Setelah diadakan tes ternyata siswa mendapat nilai diatas 70 keatas menjadi 6 siswa, ini artinya ada peningkatan sebelumnya hanya 2 menjadi 6 siswa yang mendapat nilai diatas 70. Sedangkan nilai rata-rata kelas meningkat dari rata-rata 50 menjadi 71,25. Sedangkan ketuntasan belajar meningkat $50 \%$ yaitu dari ketuntasan pemahaman siswa pada siklus I disebabkan metode yang digunakan sebelum perbaikan pembelajaran yaitu ceramah diganti dengan metode demonstrasi dan diskusi, akan tetapi masih ada 2 siswa yang belum mencapai ketutasan belajar maka peneliti mengadakan refleksi guna mencari kekurangankekurangan pada pembelajaran siklus I. Dengan dibantu teman sejawat peneliti berdiskusi untuk merencanakan perbaikan pembelajaran siklus II.

Hasil dari tes siklus I dengan jumlah 8 siswa diperoleh data nilai sebagi berikut: 40, 60, $70,70,80,80,80,90$. Nilai rata-rata kelas 71,25 dan disajikan dalam tabel 5. sebagai berikut:

Tabel 5. Nilai Tes Formatif Siklus I

\begin{tabular}{|l|l|l|}
\hline No & Rentang Nilai & $\begin{array}{l}\text { Jumlah } \\
\text { Siswa }\end{array}$ \\
\hline 1 & $20-29$ & - \\
\hline 2 & $30-39$ & - \\
\hline 3 & $40-49$ & 1 \\
\hline 4 & $50-59$ & - \\
\hline 5 & $60-69$ & 1 \\
\hline 6 & $70-79$ & 2 \\
\hline 7 & $80-89$ & 3 \\
\hline
\end{tabular}




\begin{tabular}{|l|l|l|}
\hline 8 & $90-100$ & 1 \\
\hline Jumlah & 8 \\
\hline
\end{tabular}

3. Perbaikan Pembelajaran Siklus II

Pada siklus II, peneliti menyusun Rencana Perbaikan Pembelajaran (RPP) dengan menitikberatkan pada metode dan penggunaan media pembelajaran untuk lebih menarik perhatian siswa dalam belajar. Ternyata setelah dilaksanakan siklus II hasilnya nilai formatif siswa lebih meningkat, data nilai adalah

Dari ketiga tabel nilai diatas nilai formatif siswa, baik sebelum perbaikan, siklus I, siklus II dapat disajikan dalam tabel rekapitulasi sebagai berikut: 60, 70, 70, 80, 80, 90, 90, 90. Nilai rata-rata kelas 8 dapat disajikan dalam tabel 6. sebagai berikut:

Tabel 6. Nilai Tes Formatif Siklus II

\begin{tabular}{|l|l|l|}
\hline No & Rentang Nilai & $\begin{array}{l}\text { Jumlah } \\
\text { Siswa }\end{array}$ \\
\hline 1 & $20-29$ & - \\
\hline 2 & $30-39$ & - \\
\hline 3 & $40-49$ & - \\
\hline 4 & $50-59$ & - \\
\hline 5 & $60-69$ & 1 \\
\hline 6 & $70-79$ & 2 \\
\hline 7 & $80-89$ & 2 \\
\hline 8 & $90-100$ & 3 \\
\hline Jumlah & 8 \\
\hline
\end{tabular}

Dari ketiga tabel nilai formatif dapat disajikan dalam tabel 7 rekapitulasi sebagi berikut:

Tabel 7. Rekapitulasi Nilai Formatif kelas II

\begin{tabular}{|l|l|l|l|l|l|}
\hline $\begin{array}{l}\text { N } \\
\text { o }\end{array}$ & $\begin{array}{l}\text { Kegiatan } \\
\text { Tes } \\
\text { Formatif }\end{array}$ & $\begin{array}{l}\text { Jum- } \\
\text { lah } \\
\text { Siswa }\end{array}$ & $\begin{array}{l}\text { Jum- } \\
\text { lah } \\
\text { Nilai }\end{array}$ & $\begin{array}{l}\text { Nilai } \\
\text { Rata- } \\
\text { rata }\end{array}$ & $\begin{array}{l}\text { Ketu } \\
\text { ntas } \\
\text { an } \\
\text { Bela } \\
\text { jar } \\
(\%)\end{array}$ \\
\hline 1. & $\begin{array}{l}\text { Sebelum } \\
\text { Perbaikan }\end{array}$ & 8 & 400 & 50 & $\begin{array}{l}25 \\
\%\end{array}$ \\
\hline 2. & $\begin{array}{l}\text { Perbaikan } \\
\text { Siklus I }\end{array}$ & 8 & 570 & 71,25 & $\begin{array}{l}75 \\
\%\end{array}$ \\
\hline 3. & $\begin{array}{l}\text { Perbaikan } \\
\text { Siklus II }\end{array}$ & 8 & 630 & 80 & $\begin{array}{l}87, \\
5 \%\end{array}$ \\
\hline
\end{tabular}

\section{SIMPULAN}

Setelah melakukan pembelajaran kooeporatif tipe NHT (Numbered Heads Together) pada pembelajaran tematik mata pelajaran matematika dengan menggunakan pemanfaatan alat peraga sederhana dapat diambil kesimpulan dan saran sebagai berikut :

\section{Simpulan}

a) Dari hasil evaluasi individu yang diberikan sebelum menggunakan model pembelajaran tipe NHT (Numbered Heads Together) berupa pemanfaatan alat peraga sederhana, hanya ada 2 anak dari 8 siswa yang sudah mengerti tentang pembagian bilangan dua angka tersebut, itu artinya hanya $25 \%$ siswa yang mampu dan sisanya sebanyak 6 siswa atau $75 \%$ siswa yang belum mampu.

b) Setelah melakukan kajian tentang media pembelajaran berupa pemanfaatan alat peraga sederhana tersebut, minat dan hasil belajar siswa meningkat menjadi 7 siswa $(87,5 \%)$. Sedangkan 1 siswa $(12,5 \%)$ perlu pengayaan dan bimbingan secara individu, hal ini disebabkan karena siswa tidak mengikuti pelajaran atau tidak masuk sekolah saat pembahasan materi diberikan.

c) Model pembelajaran Cooperative tipe NHT (Numbered Heads Together) pada mata pelajaran matematika sangat efektif membantu penulis dalam meningkatakan kinerja guru dalam setiap pembelajaran yang diberikan kepada siswa pada pembelajaran tematik khususnya pada pembelajaran matematika pokok bahasan pembagian bilangan dua angka.

d) Interaksi siswa dan guru sangat diperlukan dalam setiap pembelajaran sehingga materi yang diberikan dapat diserap oleh siswa, salah satunya dengan metode bermain sambil belajar.

e) Dengan hasil penelitian yang sudah dilakukan penulis tersebut, dapat dipastikan bahwa pembelajaran yang menggunakan media belajar yang konkret yaitu alat peraga sederhana (lidi, batu kerikil) ternyata dapat meningkatkan minat dan hasil belajar siswa.

\section{Saran}

Untuk menunjang kegiatan pembelajaran di sekolah, khususnya pembelajaran tematik, perlu adanya inovasi dan kreativitas dalam penyampaian. Salah satu bentuk atau model pembelajaran adalah dengan menggabungkan model tematik untuk kelas rendah digabungkan dengan model pembelajaran Cooperative tipe NHT (Numbered Heads Together)

Pembelajaran alangkah baiknya jika guru melibatkan siswa dalam kegiatan belajar mengajar, tidak hanya menggunakan tipe belajar konvensoinal saja, yang pada akhirnya tidak terpenuhi standart ketuntasan minimal dalam pembelajaran. 


\section{DAFTAR PUSTAKA}

Achmad DS. 1996. Pengelolaan Kegiatan Belajar Mengajar Sekolah Dasar. Jakarta: Depdikbud.

Degeng, Nyoman Sudana.1997. Strategi Pembelajaran. Malang: Ikip Malang

Depdikbud. 2004. Kurikulum Pendidikan Dasar, Garis-garis Program Pengajaran $(G B P P)$. Jakarta: Depdikbud

Harmini,Sri. 2004. Model Bermain Sebagai Upaya Meningkatkan Pemahaman Siswa Terhadap Operasi Penjumlahan dan Pengurangan Bilangan Cacah Di Kelas III SD. Hasil Penelitian, tidak diterbitkan : Universitas Malang

Herdian. (2009). Model Pembelajaran NHT (Numbered Heat Together). Diakses dari http://herdy07.wordpress.com/2009/0 4/22/model-pembelajaran-nhtnumbered-head-together/. Pada tanggal 8 Mei 2015, jam 17.30 WIB

Mulyasa, E. 2005. Menjadi Guru Profesional. Jakarta: Remaja Rosda Karya.

Legowo, Sapto (2006), Penggunaan Alat Peraga Permainan Dakon, Widya Tama Vol 3 No 1 Maret.

Sri Rahayu, 2009. Numbered Head Together. Diakses dari http://pelawiselatan.blogspot.com/200 9/03/numbered-head-together/ pada tanggal 23 April 2015. 